\title{
Identidade conservadora sob o rastro da Desconstrução
}

\author{
Alexandre de Oliveira Fernandes (UFRJ/IFBA)* \\ https://orcid.org/0000-0002-1556-4373
}

\section{Resumo:}

Endividado que está com o pensamento da Desconstrução, o presente artigo busca rasurar a categoria identidade, demonstrando equívocos e armadilhas de uma identidade reacionária. Identidade só é interessante se for extrema, se estremecer, preservando o tremor do deserto do deserto, ali onde as incertezas se produzem e nos convidam a decidir, se se espelhar na angústia úmida do nada e para o nada e daí, transbordar colaborando para a anulação de toda diferença ontológica, rígida, hiperbólica e por vezes, cínica, fazendo ruir toda possibilidade de privilégios. Digo, a identidade só será interessante se for úmida, erótica, mestiça, em devir, em différance.

Palavras-chave: Identidade; Identidade reacionária; Desconstrução; Différance.

\section{Abstract:}

\section{Conservative Identity in the Wake of Deconstruction}

Indebted with thinking in terms of deconstruction, this article seeks to erase the category of identity, showing the mistakes and pitfalls of an identity that is reactionary. Identity is only interesting if it is extreme, if it shudders, preserving quivers of the desert of all deserts, where uncertainties are produced and invite us to decide if it is mirrored in the humid anguish of nothingness, and then, overflows, collaborating for the annulment of all ontological differences, rigid, hyperbolic and sometimes cynical, causing the collapse of the possibility of privileges. It is to say that identity will only be interesting if it is humid, erotic, mixed, in becoming, in différance.

Keywords: identity, reactionary identity, deconstruction, différance.

Todos os gestos são, aqui, necessariamente equívocos.

Jacques Derrida (2001, p. 23)

Advertência: Não aplainar a identidade

* Doutor em Ciência da Literatura (UFRJ), Professor do Instituto Federal de Educação da Bahia (IFBA) Porto Seguro/BA. E-mail: alexandre.pro@gmail.com 
Quando recebi o convite do querido amigo e Professor Doutor Ricardo Diógenes para uma fala durante componente ministrado por ele e pela Professora Doutora Cristiane Maria Ribeiro, qual seja, "Educação, diversidade e cidadania", dentro do escopo do "Mestrado Profissional em Ensino para a Educação Básica" (PPGENEB) do Instituto Federal Goiano (IFGoiano), pensei em conversar sobre um tema amplo, "Estudos da Diferença".

Para além da pedante proposição, minha ideia - que não é tão minha assim - não foi a de passar os "Estudos da Diferença" em revista, apontando encontros e desencontros, limites e desafios. Também não pretendia equacionar - como se possível o fosse - o pensamento da diferença desde Martin Heidegger, passando por Gilles Deleuze, Jacques Derrida e Judith Butler, seja porque seria uma empresa de monta praticamente interminável, seja porque, levando em conta o limite do gênero textual "artigo", Valentina Vargas e Rodolfo Guzmán (2017) já contrastaram habilmente o "pensamento da diferença”. Delimitaram conceitualmente a diferença entre autores como Heidegger, Deleuze, Derrida e Jean-Luc Nancy, propondo a diferença colonial, a partir de uma mirada decolonial (WALSH, 2007; CASTRO-GÓMEZ; GROSFOGUEL, 2007). Sugeriram uma radicalidade ética da diferença, denunciando a hierarquia excludente/dominadora que se impõe sobre o sujeito alterizado.

Respondendo afirmativamente à interpelação de Ricardo Diógenes e Cristiane Maria Ribeiro, ao dizer-lhes "sim", pensei em convidá-las, a elas e a suas estudantes de Mestrado, para pensarmos a categoria "identidade", não evidentemente, compreendendo um ser branco ou um ser negro, um ser homem e um ser mulher, como sujeitos de uma diferença imanente. Logo, pensei em acolher a categoria "identidade" numa filosofia úmida e mestiça da diferença (OSANIIYI, 2019), muito mais interessado que estou em produzir um dispositivo de identificações não essencialista, cujo propósito é político. Isto é, acolho a identidade como o fortalecimento de direitos e a ampliação da democracia, muito mais do que com o propósito de edificar um aporte ontológico sustentado pela mesmidade fundante e reacionária.

Há um valor estratégico em tratar de identidade como política porque exprime um desejo por justiça social, empoderamento dos grupos historicamente marginalizados, contudo, tal empresa deve ser contingente e provisória, até porque, toda identidade (seja ela de esquerda, seja de direita) pode gestar em si um totalitarismo. Assim, deve-se abandoná-las a todas, em face de um universalismo, para não incorrer no risco de ao insistir em totalidades fragmentárias, favorecer auto preconceito e segregação (DUNKER, 2017, p. 299). 0 trabalho que ora lhes apresento, endividado que está com o pensamento da desconstrução, buscará rasurar a categoria identidade, demonstrando equívocos e armadilhas de uma identidade conservadora. A ideia é nos desviarmos do essencialismo estratégico, embora seja importante positivar identidades rebaixadas, tanto quanto denunciar os problemas da identidade reacionária e afirmar um humanismo revolucionário possível. Minha leitura da categoria "identidade" será, portanto, desconstrutivista e diferencial, interessando-me modos de representação da alteridade, para além de qualquer identidade, porque todas, levadas às últimas consequências, conservadora ou libertária, feminista ou queer, negra ou judaica gestam a exclusão.

Por um lado, sendo a identidade um discurso reconhecidamente marcado pela per- 
da, angústia, melancolia e luto (fundamental para reinaugurar a libido à vida) e, por outro lado, um discurso paradoxal porque supostamente capaz de produzir um "outro" inteiramente conhecível, fixo e visível, não irei responder a uma pergunta topológica, qual seja, qual o lugar da identidade na contemporaneidade, seja porque já está posta uma resposta "líquida", a identidade fissurada, cindida, incapaz de dar segurança total a si mesma, não tendo a solidez de uma rocha (BAUMAN, 2005, p. 17), seja porque se sabe que as identidades são forjadas a partir de certos requisitos e armadilhas do Estado liberal (BUTLER, 2017; HAIDER, 2019).

Não me ocuparei de uma economia semiótica da identidade, buscando apontar que signos produzem sentido para a identidade. Marcarei no discurso conversador brasileiro contemporâneo, retomando discursos e agências conversadoras, especificamente em posicionamentos de Damares Alves e Jair Messias Bolsonaro, a encarnação de um tipo de subjetividade, de desejos, de valores, de ideias, de conceitos e preconceitos, assentada na escravização, no patrimonialismo, na confusão entre o público e o privado, no patriarcado misógino ${ }^{1}$. An-

1 Não se deve esperar uma crítica ao governo de direita e ao conservadorismo em sentido lato. Além de não ser esse o objetivo da escrita em tela, fecho questão com a economista Maria da Conceição Tavares que em 1995, já afirmava: “Quero mais é que governe. Já insisti: ter um governo conservador que governe bem, é o ideal para a esquerda porque ela empurra. Agora, ter um governo conservador que não governa é uma droga. Por que você faz o quê? Penetra nas brechas, levanta a opinião pública. Mas a opinião pública está exausta. Lembra, amigo? As Diretas, quantos anos de espasmos, quantas vezes esse povo foi às ruas, quanta coragem mais vocês querem que esse povo tenha? Tem que ter uma coragem infinita. Era bom que esse governo tomasse tino e fizesse o possível por estabilizar não apenas as expectativas e se deslocasse para o centro (...), senão a gente não vai a lugar nenhum". Roda corada que está em fixidez e rebaixamento da complexidade do real, a identidade conservadora despreza a hermenêutica e esperneia, fundamentalista, contra a oscilação dos sentidos. Pretende esconder os subtextos ideológicos e as cenas de criação em que se arvoram seu "eu" - humanista, liberal, senhor de si, organizado e, supostamente coerente. Busca bloquear a ambiguidade dos sentidos, apegando-se a discursos estereotipados, narrados compulsivamente, reiterados quase que neuroticamente, cuja tendência cognitiva negativa vai do irresponsável rebaixamento da democracia e da política à violência contra a Vida. Não à toa seu paralelo com a xenofobia, racismo, colonialidade, sua sanha pela apropriação e conservação do capital, fundamentalismo econômico e religioso, seu flerte com o fascismo.

\section{A "chave" (falo)conservadora}

Especialmente após o golpe civil-cristão -parlamentar contra Dilma Rousseff (PT) e a eleição de Jair Messias Bolsonaro², está em curso no Brasil um novo conservadorismo. Parto da ideia de que essa identidade conservadora em curso, coaduna-se com

Viva. Maria da Conceição Tavares, 1995. Disponível em https://www.youtube.com/watch?$\mathrm{v}=x K X T$ _gfBbIA. Acesso em 16 jul 2020.

2 Jair Messias Bolsonaro, atualmente sem partido, já passou por oito partidos diferentes. Sem sombra de dúvidas, é o expoente atual da chamada ultra direita brasileira. Há mais de 20 anos na política conseguiu formar com sua família, à moda de Antônio Carlos Magalhães, Jader Barbalho e José Sarney, um verdadeiro clã. Seus filhos estão presentes no Senado, na Câmara de Deputados e na Câmara de Vereadores do Rio de Janeiro. IG. ÚLTIMO SEGUNDO. Há 20 anos na política, Bolsonaro passou por oito partidos antes de deixar o PSL. 12 nov. 2019. Disponível em: https://ultimosegundo.ig.com.br/politica/2019-11-12/ha-20-anos-na-politica-bolsonaro-passou-por-oito-partidos-antes-de-deixar -o-psl.html. Acesso em: 20 jul. 2020. 
quatro círculos: "Família", "Propriedade", "Pátria", sendo Deus o "círculo maior", sendo seu traço mais significativo, "a suspensão do seu tradicional universalismo liberal e a retomada da retórica particularista da família, da ordem e da religião" (DUNKER, 2017, p. 277). Teria a arma como o "bastão da chave" e a cruz e a bandeira como "valores morais e éticos cristãos da sociedade"3 (figura 1).

Frequentemente, a identidade conservadora se queixa de ter sua liberdade ameaçada por quem teria interesses alheios aos republicanos e logo conclama o "sujeito de bem $^{4 "}$, evidentemente conservador e belico$\mathrm{so}^{5}$, à luta, pois ora, "um povo armado jamais

3 TWITTER. Acima, dei minha interpretação sobre o símbolo da chave conservadora. $24 \mathrm{de}$ jun de 2020. Disponível em https://twitter.com/ LuizEloy/status/1275977395053436928. Acesso em 10 de jul de 2020.

4 Em mídia social, Bernardo P Küster, o qual se identifica como Diretor de Opinião do @jornalBSM, ensaísta, palestrante e tradutor, é possível encontrar vídeo com a seguinte legenda "Casal em St. Louis defende sua casa contra terroristas. Um povo armado jamais será escravizado". No vídeo vemos um casal branco, armado, em frente a casa "enfrentando" manifestantes, em sua maioria negros, portando celulares. $\mathrm{Ou}$ ve-se ao fundo sons e palavras de ordem como "pessoas se movimentem", "vamos lá". Acesso em 10 julho de 2020. 0 vídeo conta com pouco mais de 7 mil retweets e 30 mil likes. Disponível em https://twitter.com/bernardopkuster/ status/1277447621049749509. Küster tem afixado em seu twiiter a seguinte mensagem: "Já cancelou sua assinatura na grande mídia hoje? Estadão: 08000147720 Folha: 0800140090 Globo: 08008818000 Veja: 08007752112 ISTOÉ: 0800888 2111". Acesso em 10 julho de 2020. Disponível em https://twitter.com/bernardopkuster.

50 sujeito conservador também age através de um discurso belicoso como se estivesse lutando numa guerra. Ouçamos o ministro da Economia do Brasil, Paulo Roberto Nunes Guedes: “(...) A outra coisa são as torres do inimigo que a gente tinha que derrubar. Uma era o excesso de gasto na previdência, derrubamos assim que entramos. A segunda torre eram os juros. (...) todo mundo tá achando que tão distraído, abraçaram a gente, será escravizado6". Convoca seus adeptos a engrossar as "fileiras do exército conservador", queixando-se de liberdades tolhidas, logo, propaga a necessidade de defender os quatro pilares que sustentariam nossa sociedade $^{7}$ : Deus, pátria, família, propriedade (figura 2).

\section{Figura 1 - Chave conservadora ${ }^{8}$}

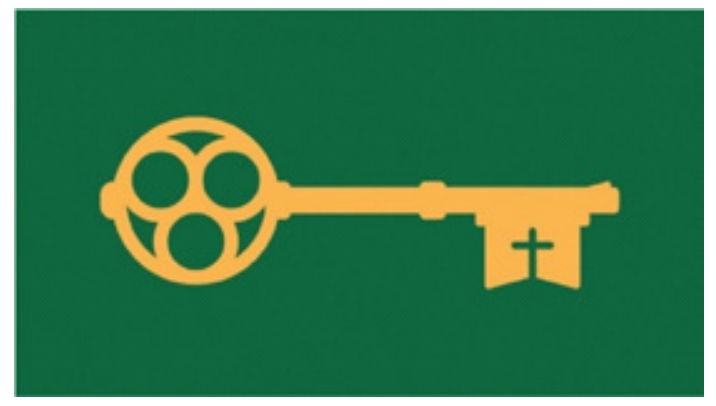

enrolaram com a gente. Nós já botamos a granada no bolso do inimigo. Dois anos sem aumento de salário. Era a terceira torre que nós pedimos pra derrubar. Nós vamos derrubar agora, também. UOL, São Paulo. Política. Leia a íntegra da reunião ministerial de 22 de abril. 22 de maio de 2020. Disponível em: https://noticias.uol. com.br/politica/ultimas-noticias/2020/05/22/ confira-a-integra-da-degravacao-da-reuniaoministerial-de-22-de-abril.htm. Acesso em: 10 jul. 2020.

6 Em reunião ministerial, o presidente Jair Bolsonaro afirmou: "É escancarar a questão do armamento aqui. Eu quero todo mundo armado! Que povo armado jamais será escravizado". Esta reunião foi divulgada pela mídia após o ministro do Supremo Tribunal Federal (STF), Celso de Mello derrubar sigilo desse encontro ministerial que ocorrera em 22 de abril de 2020. Nessa mesma reunião, o presidente da Caixa Econômica Federal. UOL, São Paulo. Política. Leia a íntegra da reunião ministerial de 22 de abril. 22 de maio de 2020. Disponível em: https://noticias.uol.com.br/politica/ultimasnoticias/2020/05/22/confira-a-integra-dadegravacao-da-reuniao-ministerial-de-22-deabril.htm. Acesso em: 10 jul. 2020.

7 TWITTER. Finalizando. 25 de jun de 2020. Disponível em: https://twitter.com/LuizEloy/ status/1276120384669200386/photo/1. Acesso em: 10 jul. 2020.

8 Twitter. Nossa liberdade nunca foi tão ameaçada. 25 de jun de 2020. Disponível em: https://twitter.com/LuizEloy/status/1276120384669200386/photo/1. Acesso em 10 jul. 2020. 
Figura 2 - Direto à defesa ${ }^{9}$

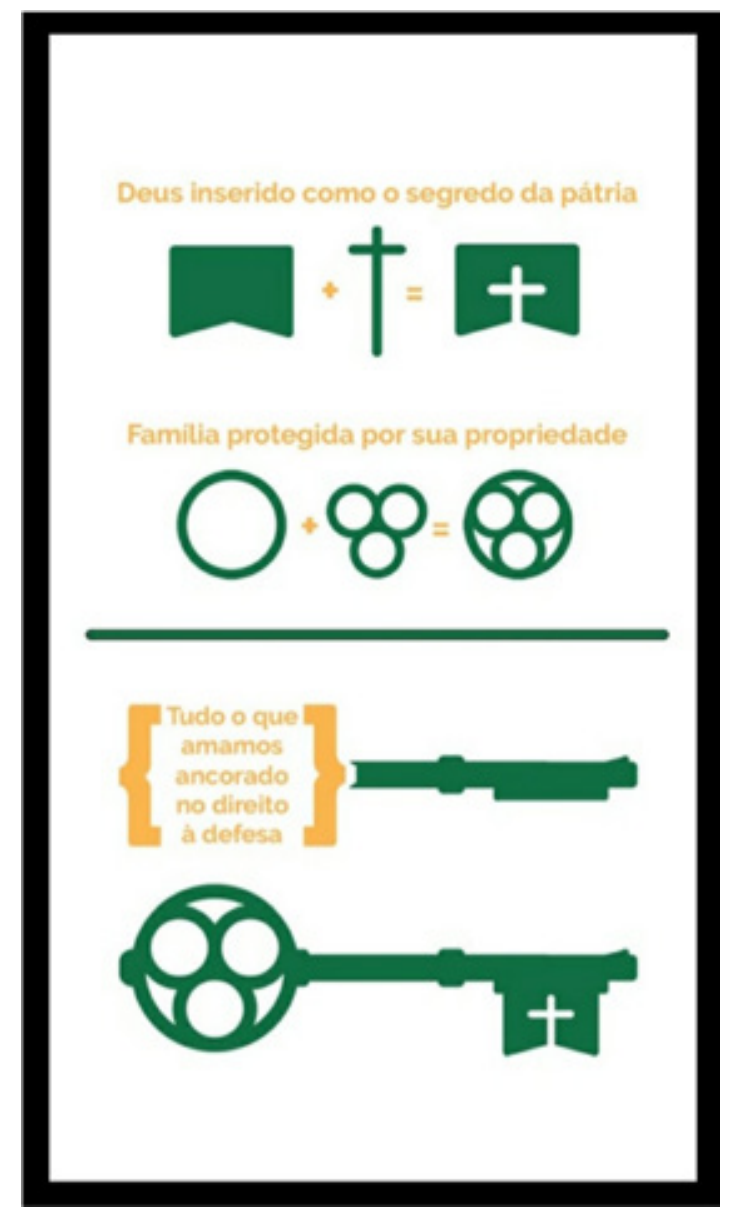

A "chave conservadora" é um símbolo fálico, um brasão, um escudo, um emblema. Em uma das pontas desse membro está representado pelos quatro círculos, "tudo o que amamos ancorado no direito à defesa" - "Família", "Propriedade", "Pátria", "Deus" - na outra extremidade, na ponta da espingarda, do revólver, vê-se uma flâmula simbolizando o Brasil e a cruz cristã. A chave é amarela e está em um fundo verde, evocando cores da bandeira nacional.

Deus - judaico-cristão e não de qualquer outra religiosidade -, é inserido como o segredo da pátria e abarca o todo. Esse "Deus", uma verdade em si, plena e incorrigível, desempenha papel fundamental na arqui-

9 Twitter. Acima, dei minha interpretação sobre o símbolo da chave conservadora. 24 de jun de 2020. Disponível em: https://twitter.com/ LuizEloy/status/1275977395053436928/photo/1. Acesso em 10 jul 2020. tetura de uma ficção necessária e interminável(mente) frágil. Não se sabe, ao analisar o cartaz, quem "insere" Deus e de que "segredo" se trata, ou se apenas se configura o "segredo" capaz de abrir portas - cabendo arguir para quem e de que portas se trata? -, tanto quanto é de difícil apreensão a frase "Família protegida por sua propriedade". Ora, nessa sentença deve-se questionar se é a propriedade, ganhando ares de humanidade, quem protege a família? Nas três sentenças presentes em "Direito à defesa" (figura 2) saltam, elípticos, vocábulos que aguçam a propriedade: "(Nosso) Deus inserido (por nós) como o segredo da pátria"; (Nossa) Família protegida por sua propriedade"; "Tudo o que (nós) amamos ancorado no direito à (nossa) defesa".

A identidade conservadora se aproxima do que Edward Said (2011) denominou de realismo radical, qual seja, seu tempo é atemporal, seu discurso é reiterativo, age por meio da repetição e da força. Aqui não há independência à cadeia de significantes senão um essencialismo sincrônico (tempo e discurso se imantam) por meio do que, o conhecimento das cenas de construção dos pares opositivos é bloqueado. A história para a identidade conservadora é "presentista". Sancionada por uma visão burguesa, patriarcal-cristã e, ao menos inicialmente, liberal de mundo ${ }^{10}$, sua verdade não cultiva

10 Como olvidar o toma-lá-dá-cá da velha política colocado em curso pelo novo conservadorismo liberal de Jair Messias Bolsonaro? Seus movimentos governamentais em relação à luta contra a corrupção têm sido questionados, pois demonstram um descompasso entre o que vocaliza o presidente e suas ações. Sabe-se que não houve apoio a seu ministro da Justiça e ao pacote anticorrupção, além do que não apoiou prisão em segunda instância. 0 Presidente coloca diuturnamente em questão a Democracia e Instituições essenciais à liberdade, além de ser corrente o envolvimento de pessoas muito próximas a seu governo com crimes a serem 
incertezas porque está atrelada a uma metanarrativa fálico-religiosa, a um modo de estabilidade "tradicional”, a uma ficção centralizadora e hierarquizada.

Os saberes prático e religioso são levados a termo, desde que atendam aos ditames de sua tradição reacionária, tanto quanto fortaleçam uma tropa de defesa de reformas sociais. Mas, não nos apressemos, contudo. Essas "reformas" não se interessam por movimentar as estruturas que sustentam as desigualdades. Ser conservador é privilegiar certo humanismo aliado dos ditames da sociedade vigente (não qualquer uma, mas aquela alinhada à tradição), procedendo a "mudanças", desde que não signifiquem abalar o status quo. Valores morais, éticos e a propriedade privada devem ficar intocáveis, conquanto se deva intensificar a incitação à denúncia, o reforço corporativo e o controle da expressão jornalística e artística.

A identidade conversadora deixa ler em sua agência uma economia de significantes

apurados, como o das "rachadinhas". Por exemplo: CNN Brasil. Deltan diz que Governo e aliados agem contra Lava Jato para enfraquecer Moro em 2022. Disponível em: https://www.youtube. com/watch?v=VS5Bnm86y7U. Acesso em: 10 jul. 2020. O Presidente da República tem a imprensa como inimiga e incita seus ministros para que não dialoguem com os veículos de comunicação porque estariam distorcendo as informações: "A questão da imprensa. Eu acho que eu resumi hoje na frente do palácio em vinte segundos: 'Eu não vou falar com vocês, porque vocês não deturpam, vocês inventam, e potencializam'. Tem que ser o papel de cada um (...). Tem que ignorar esses caras, cem por cento. Senão a gente não, não vai para frente. A gente tá sendo pautado por esses pulhas, pô. 0 tempo todo jogando um contra o outro. (...) 0 tempo todo, tá? Então se a gente puder falar zero com a imprensa é a saída. UOL, São Paulo. Política. Leia a íntegra da reunião ministerial de 22 de abril. 22 de maio de 2020. Disponível em: https://noticias.uol. com.br/politica/ultimas-noticias/2020/05/22/ confira-a-integra-da-degravacao-da-reuniaoministerial-de-22-de-abril.htm. Acesso em: 10 jul. 2020. e significados, que se querem, em sua montagem, sempre estáveis. 0 referente nem é textualizado nem contextualizado, porque teme formas diacrônicas de se contar a história e as narrativas em performance, tanto quanto não lida bem com signos da instabilidade. Uma vez que sua suposta plenitude de imagem/identidade estereotipada poderia se ver atacada/assombrada pela "falta" ou pelo "excesso", não lida bem com outras formas de família, com outros modos de tratar a terra e a natureza ${ }^{11}$.

Recentemente, o ministro do Meio Ambiente, Ricardo Salles, em reunião de 22 de abril de 2000, defendeu, em suas palavras, passar "a boiada" e "mudar" marcos legais relacionados à terra enquanto a atenção da mídia se volta para a pandemia do novo corona vírus - Covid-1912. Esse tipo de pensamento contrasta com as ideias do indígena Ailton Krenak (2019) para "adiar o fim do mundo", segundo as quais, é fundamental rasurar a ideia de humanidade e os padrões de existência atual porque essa "humanida-

11 G1. Política. Ministro do Meio Ambiente defende passar 'a boiada' e 'mudar' regras enquanto atenção da mídia está voltada para a Covid-19. 22 de mai. 2020. Disponível em: https:// g1.globo.com/politica/noticia/2020/05/22/ ministro-do-meio-ambiente-defende-passara-boiada-e-mudar-regramento-e-simplificarnormas.ghtml. Acesso em: 10 jul. 2020.

12 Nas palavras do ministro: "Precisa ter um esforço nosso aqui enquanto estamos nesse momento de tranquilidade no aspecto de cobertura de imprensa, porque só fala de Covid, e ir passando a boiada e mudando todo o regramento e simplificando normas (...) Agora é hora de unir esforços pra dar de baciada a simplificação de regulatório que nós precisamos, em todos os aspectos (...) Tem uma lista enorme, em todos os ministérios que têm papel regulatório aqui, pra simplificar. Não precisamos de Congresso. PODER 360. Salles diz que 'passar a boiada' significa simplificar normas. Disponível em: https://www.poder360.com.br/governo/sallesdiz-que-passar-a-boiada-significa-simplificarnormas/ Acesso em 10 jul. 2020. 
de" é signatária de diversas formas de violência. Krenak apoia seus pensamentos em sua ancestralidade e em sujeitos diversos como José Mujica, Boaventura Souza Santos, Eduardo Galeano, o pajé yanomami Davi Kopenawa, Eduardo Viveiro de Castro.

O descompasso é evidente: Ricardo de Aquino Salles, principal referência do "Movimento Endireita Brasil", defende o liberalismo econômico, a diminuição do Estado e o fim de mecanismos que limitem liberdades individuais. Expressamente, afirmou que "simplificar o ambiente regulatório, desburocratizar, é um dever do Poder Executivo, em todos os momentos"13, enquanto Krenak compreende ser o rio uma pessoa com subjetividade própria e não um recurso que deve estar à disposição do Projeto da Modernidade, qual seja, um exercício para a exaustão da natureza. Na seara da identidade conservadora deve-se submeter à história única, ao pensamento único e, portanto, perigoso, sem a plena aceitação e subsequente experimentação do pluralismo sócio -étnico-político-cultural.

A identidade que se quer conservadora deve ser constantemente reposta e reafirmada. $\mathrm{O}$ dano começa quando "minha identidade de gozo tende sempre a ser imposta ao meu vizinho" porque a identidade do semelhante é ameaçadora e impõe riscos para minha fantasia narcísica (DUNKER, 2017, p. 297). Logo, apenas o meu Deus salva e, perdoe-se a ironia, mas tudo parece "cair do céu" tanto quanto Jesus resolve aparecer no "pé de goiabeira"14 para me salvar dos "meus" problemas, dores e agonias.

13 TWITTER. Endireita Brasil. Disponível em https://www.instagram.com/p/CAk56yup9zZ/. Acesso em 15 jul. 2020.

14 CATRACA LIVRE. Damares garante que conversou com Jesus num pé de goiaba. https:// catracalivre.com.br/cidadania/ministradamares-garante-que-conversou-com-jesusnum-pe-de-goiaba/
O referente não é, para a identidade conservadora, uma entidade discursiva, ela não questiona a maneira como conhecemos, como é ou foi uma dada "realidade" a não ser para se retroalimentar, fortalecendo sua "tradição". Aliás, sua realidade não tem aspas, mas uma existência natural e autorreferente a si e ao seu Deus único.

Ocorre que há um triplo drama, ao menos, na construção da identidade que se quer fixa. Há um drama como um teatro, uma cena, uma construção com holofotes, sistemas integrados de comunicação, discursos diversos, tempo, história, cultural, disputas pelo poder. Nenhuma identidade pode ser natural senão manietada por discursos e linguagens de toda ordem. Assoma-se um outro drama, qual seja, uma fatalidade, uma dor, um melodrama, um sofrimento, porque toda identidade acena para o desejo impossível de uma origem pura e homogênea. Sucede-se o drama que delimita os discursos e exerce papel coercitivo nas cenas de subjetivação, ou seja, interpela, violenta e circunscreve as pessoas a ações controladas.

Toda identidade, singular e conversadora, na expressão de Christian Dunker (2017a), toda vida condominial - com sua ordem, limpeza, segurança e funcionalidade, espaço em que se está entre iguais, protegido - , seja de esquerda, seja de direita - emana estereótipos ambivalentes e complexos de projeção e introjeção de estratégias narcísicas, metafóricas e metonímicas, repletos de culpa e agressividade, ressentimentos e luto, de encobrimento e ruptura, com vistas a construir posições e oposições, alegrias e ódios, situação e detrator, de modo que lega rastros da formação de sua identidade.

Se há rastros, não pode surgir do nada para o nada. No mais fundo de sua imagem está impressa o rasto indelével do outro 
(SLOTERDIJK, 2009, p. 29), o qual, é construído como inimigo a ser combatido.

Não sem desenhar um opositor, qual seja, a ditadura, em reunião ministerial, ocorrida em 22 de abril de 2020, o presidente Jair Bolsonaro solicitou que o ministro da Defesa, Fernando Azevedo, e o ministro da Justiça e Segurança Pública, Sergio Moro, assinassem portaria relativa ao aumento de limite de compra de munições por pessoas físicas autorizadas a adquirir ou portar arma de fogo ${ }^{15}$ :

0 que esses filha de uma égua quer, ô Weintraub, é a nossa liberdade. Olha, eu tô, como é fácil impor uma ditadura no Brasil. Como é fácil. 0 povo tá dentro de casa. Por isso que eu quero, ministro da Justiça e ministro da Defesa, que o povo se arme! Que é a garantia que não vai ter um filho da puta aparecer pra impor uma ditadura aqui! Que é fácil impor uma ditadura! Facílimo! Um bosta de um prefeito faz um bosta de um decreto, algema, e deixa todo mundo dentro de casa. Se tivesse armado, ia pra rua. E se eu fosse ditador, né? Eu queria desarmar a população, como todos fizeram no passado quando queriam, antes de impor a sua respectiva ditadura. Aí, que é a demonstração nossa, eu peço ao Fernando e ao Moro que, por favor, assine essa portaria hoje que eu quero dar um puta de um recado pra esses bosta! Por que que eu tô armando o povo? Porque eu não quero uma ditadura! E não dá pra segurar mais! Não é? Não dá pra segurar mais ${ }^{16}$.

15 BRASIL, DIÁRIO OFICIAL DA UNIÃO. Portaria interministerial $n^{\circ} 1.634$, de 22 de abril de 2020. Publicada em 23 abril de 2020. Edição: 77, seção: 1, p. 22. Disponível em: http://www.in.gov.br/ web/dou/-/portaria-interministerial-n-1.634/ gm-md-de-22-de-abril-de-2020-253541592. Acesso em: 10 jul 2020.

16 UOL, São Paulo. Política. Leia a íntegra da reunião ministerial de 22 de abril. 22 de maio de 2020. Disponível em: https://noticias.uol. com.br/politica/ultimas-noticias/2020/05/22/ confira-a-integra-da-degravacao-da-reuniaoministerial-de-22-de-abril.htm. Acesso em: 10 jul. 2020.
Como pode ser ela, a identidade conservadora, natural, no sentido de transcendente? Como poderia girar em torno de si e se autoexplicar como se no éter estivesse boiando e nunca fosse acometida, porque partiria de um lugar natural, de um não-lugar, por isso mesmo não sendo acossada indefinidamente por signos substituindo outros signos? Ora, aquilo que seja uma identidade nos chega por meio da différan$c e$, "no qual o significado central, originário ou transcendental nunca está absolutamente presente fora de um sistema de diferenças (DERRIDA, 2009, p. 410). Seu sentido chegante, por vir, adiado e diferido, só pode provir do interior de "textos" - até porque, o que há fora de textos que possa nos chegar sem vir molhado por textos e mais textos, interpretações de interpretações -, por meio da disseminação de significantes de significantes, os quais, ao produzir sentido, mais postergam e escondem do que revelam algo substancial, verdadeiro e único.

\section{A identidade conversadora}

A identidade conservadora retroalimentase de "mitos" em sua estrutura, como a senhora Damares Alves, à frente do "Ministério da Mulher, da Família e dos Direitos Humanos", que compõe o gabinete executivo do Governo Federal do Brasil, sob a presidência de Jair Messias Bolsonaro, cujas bandeiras são, segundo o próprio presidente, "família, Deus, Brasil, armamento, liberdade de expressão, livre mercado"17.

Certa feita, a ministra usou, segundo ela, uma "metáfora" contra o que denomina

17 UOL, São Paulo. Política. Leia a íntegra da reunião ministerial de 22 de abril. 22 de maio de 2020. Disponível em: https://noticias.uol. com.br/politica/ultimas-noticias/2020/05/22/ confira-a-integra-da-degravacao-da-reuniaoministerial-de-22-de-abril.htm. Acesso em: 10 jul. 2020. 
como ideologia de gênero ${ }^{18}$, qual seja, "menino veste azul e menina veste rosa ${ }^{19 " . ~ E m ~}$ um cenário possível, a ministra não deve saber o que seja "metáfora", noutro, terei de acolher sua assertiva como uma metáfora desgastada de sua própria e egocêntrica mesmidade (SKLIAR, 2003, p. 23), uma condição ordinária, natural e autoritária, uma violência que arroga para si o direito de produzir e ordenar toda a diferença.

A dicotomia e a nuvem de estereótipos contidos na "metáfora" ministerial são um gesto que consiste em arrogar uma origem fixa, um ponto de presença, escrevendo em palimpsesto, com tinta "branca", o princípio de organização da estrutura cisgênera, heteronormativa e burguesa, buscando limitar o que Jacques Derrida chamou de "jogo da estrutura" (DERRIDA, 1991). Trata-se de retórica conservadora que destila aversão à diferença e produz identidades heterossexuais agressivas. São ruminações de pensamento assentadas na história do Ocidente, em uma metafísica que busca apagar em si mesma a cena fabulosa que a produziu e que permanece, no entanto, ativa, turbulenta, inscrita com tinta branca (DERRIDA, 1991, p. 254) em suas desgastadas metáforas e metonímias, pseudociência e literatura de baixa qualidade, acometida por nódulos de ilusões seculares, centro de expressão de

18 Richard Miskolci e Maximiliano Campana (2018) traçaram genealogia do termo "ideologia de gênero", buscando compreender a gramática política em que está inserido. Seu artigo demonstra como esse termo tem sido utilizado a mais de 20 anos para gerar pânico moral e posicionamentos reativos às demandas por avanços nos direitos sexuais e reprodutivos.

19 G1. POLÍTICA. Damares diz que fez "metáfora" e que meninos e meninas podem vestir "azul, rosa, colorido". 03 jan 2010. Disponível em: https://g1.globo.com/politica/ noticia/2019/01/03/damares-diz-que-videoe-metafora-e-que-meninos-e-meninas-podemusar-qualquer-cor.ghtml. Acesso em 15 jul. 2020. uma feminilidade, de uma masculinidade, de uma sexualidade essencializantes.

Damares é pastora evangélica e mestra em "ensino bíblico ${ }^{20}$, não em Educação ou Direito constitucional e da família, títulos que ela não obteve e, portanto, foi levada a se desmentir ${ }^{21}$. Logo após assumir cargo ministerial, pediu atenção de todos os presentes: "É uma nova era no Brasil". Em coro entusiasmado, os presentes anunciaram: "Menino veste azul e menina veste rosa".

Se me permitem a analogia nesse tópico sobre "metáforas", com Damares estamos na ceara do discurso de uma mulher mediana. Neste caso, sigo Nietzsche e Derrida e não formo meramente juízo de valor. A ministra é aquela que não cria, que "não dá à luz", que se contenta em ter discursos repetíveis, prontos na ponta da língua.

Conforme Rafael Haddock Lobo (2007, p. 69), o feminino não é "a mulher", mas sim a possibilidade de se lidar com a ausência da verdade fálica, logo, Damares se distancia da agência do feminino, do masculino e do sexo, como lidos por Jacques Derrida em Friedrich Nietzsche (2013, p. 45), esse que se ocupou da crítica à Metafísica, dos conceitos de ser e de verdade, de uma verdade contra os pudores, da história da verdade como a história dos erros, vários e tantos e sob os quais se assenta o Ocidente.

Acompanhando Nietzsche sendo lido por Derrida, percebo que, ao proferir discurso

20 HORA DO POVO. Ministra mente sobre formação acadêmica e agora diz ter mestrado “bíblico". 6 Fev. 2019. Disponível em: https:// horadopovo.com.br/ministra-mente-sobreformacao-academica-e-agora-diz-ter-mestradobiblico/ Acesso em 15 jul. 2020.

21 FOLHA. Sem diploma, Damares já se apresentou como mestre em educação e direito. 31.jan.2019. Disponível em: https:// www1.folha.uol.com.br/poder/2019/01/ sem-diploma-damares-ja-se-apresentou-comomestre-em-educacao-e-direito.shtml. Acesso em 15 jul. 2020. 
falocêntrico, para além de torná-la mulher, o enunciado por Damares Alves, "torna-a cristã". Diz-nos Derrida (2013, p. 63), “como em aposição, como para explicar e analisar o 'ela torna-se mulher', Nietzsche acrescenta 'ela torna-se cristã' e fecha parênteses".

A crítica de Nietzsche à moral tradicional, à verdade do Ocidente, aplicada à retórica de Damares Alves, delata um modo castrador de lidar com desejos, paixões e instintos, evitando transferências e demandas da vida em sociedade. Implicada em "castrar(-se); ela castra porque ela é castrada, ela joga sua castração (...)". Em outros termos, repleto de culpa, medo e sadismo, o referido enunciado pretende proibir (castrar, banir, apartar-se, separar-se de) a homossexualidade à medida que performa a heterossexualidade.

A identidade conservadora heterossexual, cisnormativa e patriarcal, manietada por imposições binárias, interdições, terrorismos e ameaças, toma a homossexualidade como um de seus objetos de renúncia e castração. Para se construir como heterossexual seria preciso se desfazer do ser homossexual. A perda desse apego, permite indagar: se um homem se torna heterossexual por repudiar a homossexualidade, onde esse repúdio poderia existir senão na identificação que sua vida heterossexual busca negar?

Daí, é preciso pôr em relevo a fixação da identidade conservadora com as questões que envolvem gênero, sexualidade e corpo, pois, vem sistematicamente ofendendo o direito à autodeterminação e à dignidade das corpas desviantes da cisheteronormatividade e, por outro lado, deve-se questionar a competência política de sua agência, haja vista que, frequentemente, em nome de uma dada tradição, golpeiam liberdades individuais, paradoxalmente ou cinicamente, caso se prefira, ou ainda repletos de culpa e, como se sabe, a culpa se demonstra pouco afeita à potência transformativa (DUNKER, 2017, p. 297), frequentemente constrangem os ditames do liberalismo por eles mesmos escudados.

Recentemente, a ministra da Mulher e dos Direitos Humanos, Damares Alves, empregou em sua pasta Sara Fernanda Gerimoni, conhecida como Sara Winter. Presa pela Polícia Federal, Winter é acusada de comandar ataques ao Superior Tribunal Federal $(\mathrm{STF})^{22}$. Sabe-se que em manifestação ocorrida no ano de 2014, chegou a "amputar" membro sexual do atual Presidente da República em favor do movimento feminista, mas hoje defende-o com arma na mão ${ }^{23}$.

Não obstante, em 2019, foi nomeada coordenadora nacional de políticas à maternidade, cargo ligado ao governo federal. 0 que ocorre aqui? É incompetente a ministra e/ou está a reforçar a "castração" pela qual tem sido atingida? Ouçamos Derrida (2013, p. 70):

A mulher está condenada, humilhada, desprezada como figura ou potência de mentira. A categoria da acusação é assim, produzida em nome da verdade, da metafísica dogmática, do homem crédulo que faz avançar a verdade e o falo como seus atributos próprios. Os textos - falogocêntricos - escritos a partir dessa instância reativa são muitos.

O homem crédulo, branco, ocidental, cuja identidade seja reacionária coloca discursos reativos na ponta da língua de "Damares", por isso, ser ela uma mulher "estéril". Por meio da interpelação, reiteração, per-

22 ISTO É. Os extremistas avançam. Disponível em:https://istoe.com.br/os-extremistasavancam/. Acesso em 12 de jul. de 2020.

23 Diário de Notícias. Sara Winter quis castrar Bolsonaro, hoje defende-o de pistola na mão. João Almeida Moreira, São Paulo. 02 jun 2020. Disponível em: https://www.dn.pt/mundo/ sara-winter-quis-castrar-bolsonaro-hojedefende-o-de-pistola-na-mao-12264269.html. Acesso em 12 de jul. de 2020. 
formance e exposição de textos falogocêntricos, ela se torna mulher, cristã, castrada e infértil. Tudo isso à serviço da verdade, da metafísica dogmática e do falo. Não se trata do feminino, muito menos da ideia de verdade nietzschiana/derridiana, mas da presença-ausência de símbolos fálicos e desejos patriarcais, os quais deixam rastros de uma pós-verdade (DUNKER, 2017, p. 130), a saber, uma maneira de institucionalizar a covardia e a crueldade, ocupando-se de meios políticos, jurídicos, sociais, midiático -religiosos, para difundir opiniões e interesses autolegitimadores.

Como fantasmas, os rastros do sentido ora lidos pela filosofia, ora explorados pela psicanálise dão o que perceber, a primeira com seu desejo e recalque pela não posse do "ente", a segunda pelo que pode nos contar sobre os desejos e traumas da sexualidade recalcada, saltam como discursos em restança, como efeitos de uma vontade de dizer/saber algo.

Que vontade de saber (diferencial, dividida, dobrada, multiplicada, mutilada, amputada, castrada) expressa? Há de haver um mal -estar contido na frase "menina veste rosa", "menino veste azul", muito melhor entendido se atentarmo-nos para o que ela silencia e não para o que ela pretende dizer. Que nos diz o discurso do macho proferido pela mulher, com suas metáforas, repetidas a muitas vozes, reiteradas por muitas vezes, signo de supostas virtudes, acometido por moralismos pedagógicos, persuasivos, coercitivos? Que recalcado está a bater, compulsoriamente, em sua porta todas as manhãs? Que necessidade de negação é essa que, a despeito do ato de negar magnetiza-lhe o objeto excluído?

Ao dizer tanto e sempre, reiteradas vezes e de múltiplas maneiras a mesma coisa, como uma fixação, paradoxalmente evoca uma impossibilidade traumática de dizer, de narrar e de nomear. Seu falar tanto e seu "nada" dizer, ecoa uma defesa contra algo muito pior, que ainda não está nomeado. E, ao não ser nomeado o problema, não se pode tratá-lo.

Deixemos essa questão aberta que é o melhor que se lhe faça. Sem castração, ofereço-lhe a (im)possibilidade da castração do sentido, na abertura do pensamento, no esgarçar do entendimento, para sempre "aberto, oferecido $e$ indecifrável, ainda que não se saiba indecifrável” (DERRIDA, 2013, p. 104), posto que reacionário, reativo, pouco reflexivo.

Todo apego à redução da realidade produz uma vida cuja experiência é maniqueísta, o que se coaduna com uma operação simplificadora que, por um lado permite constituir inimigos (comunismo, sexualidades desviantes da norma, estrangeiros, professoras/es), promove o ódio e atiça os nossos medos, por outro lado, permite que uma "verdade se estabeleça como a única e legítima, fazendo passar a complexidade do real por abstrações binárias e hierarquizadas. Daí se utilizar de pares de opostos simplificadores, os quais buscam restringir cosmopolitismos e formas mais democráticas de ser e existir, ainda que se utilize de cinismo e hipocrisia sempre que lhe convier:

A China é aquele cara que cê sabe que cê tem que aguentar, porque pro cês terem uma ideia, pra cada um dólar que o Brasil exporta pros Estados Unidos, exporta três pra China". (...) Você sabe que ele é diferente de você. Cê sabe que geopoliticamente cê tá do lado de cá. Agora, cê sabe o seguinte, não deixa jogar fora aquilo ali não porque aquilo ali é comida nossa. Nós tamo exportando pra aqueles caras. Não vamos vender pra eles ponto crítico nosso, mas vamos vender a nossa soja pra eles. Isso a gente pode vender à vontade ${ }^{24}$.

24 Ministro da Economia do Brasil, Paulo Guedes 
A produção de opostos tenta apagar o simbólico, a densidade e as disputas em torno da história, aplainando conflitos em meros "contra" e "a favor". Emerge, desse modo, sustentado por um discurso do medo, o herói mítico, salvacionista cuja espada é a verdade empunhada por Damares Alves ou qualquer outro "mito". E de que se tem medo? Do deslocamento global das populações sobre a terra, do avanço da miséria e dos conflitos bélicos em várias partes do mundo, da concorrência pelos postos de trabalho, da insegurança cotidiana nas cidades, da exclusão da "cidadania de consumo", o que gera espaço fértil para o crescimento de identidades que se querem bem marcadas e inflexíveis, expressas em nacionalismos, xenofobia, racismo, homofobia, os quais encontram salvaguarda em políticas conservadoras.

A mulher (de) Nietzsche lida pelo filósofo franco-argelino (DERRIDA, 2013, p. 106) nos diz que "deve haver mais de um", porque, a despeito de discursos estigmatizados, simplificadores e maniqueístas - "A gravidez é um problema que dura só nove meses"; "Nenhuma mulher quer abortar"; "Ninguém nasce gay"; "A mulher nasceu para ser mãe"25 -, há outras formas de ser e existir, como nos conta Iza, em entrevista a Lázaro Ramos, cantora brasileira, cuja agência é fluida e acolhedora à diferença:

se referindo à China, parceiro comercial ainda que comunista. UOL, São Paulo. Política. Leia a íntegra da reunião ministerial de 22 de abril. 22 de maio de 2020. Disponível em: https://noticias.uol.com.br/politica/ultimasnoticias/2020/05/22/confira-a-integra-dadegravacao-da-reuniao-ministerial-de-22-deabril.htm. Acesso em: 10 jul. 2020.

25 HYPNESS. 6 frases da ministra da Mulher, Família e Direitos Humanos que poderiam estar em 'Handmaid's Tale'. Disponível em: https://www.hypeness.com.br/2018/12/6frases-da-nossa-ministra-que-poderiam-estarem-handmaids-tale/ Acesso em 15 jul 2020.
Ser mulher é difícil pra caramba. Poxa, a gente tem que pensar quinze vezes na roupa que vai usar antes de sair de casa. Não por uma questão nossa, mas por segurança, mesmo. Eu não sei o que eu vou encontrar, sabe? Tudo aquilo que eu faço está condicionado a como o outro vai reagir a mim. E isso é muito difícil. A gente tem que tá pensando em como falar alguma coisa. Se você é uma pessoa decidida, você é mandona. Se você é chefe, chefe é um saco, está de TPM. É muito difícil. A gente passa por provação o tempo inteiro. E aí, quando outras mulheres cantam para outras mulheres falando sobre recalque, sobre competição, sobre inimiga, só piora. Isso eu posso assegurar. Eu estou em construção. Eu acho que toda artista evoluí, mas isso é uma coisa que eu nunca vou cantar porque machuca. É cruel demais. É difícil, por exemplo, quando eu posto uma foto e vem uma amiga e diz: "amiga, apaga aquela foto. Eu acho que você não viu, mas tem celulite na foto". E celulite é um assunto, é uma questão. É como se eu não pudesse ser realmente quem naturalmente eu sou. E ser lembrada disso por outras mulheres só piora as coisas. Eu não apoio esse movimento ${ }^{26}$.

0 ser mulher é difícil, afastando-nos de qualquer possibilidade da verdade sobre a mulher. Em seu feminino, Iza é uma verdade que afasta "a" verdade do ser mulher. E, por isso mesmo, aproxima-se da verdade. Ela deixa o cenário complexo e menos cruel, talvez, porque sua verdade acerca do que é ser mulher não implica agredir a outra mulher possível. Como sua identidade não é sólida, não precisa ser refratária à chegada do outro. Ela não participa de um movimento identitário que detém o monopólio sobre o ser mulher, está em construção, sabe-se mediada pelo que os outros pensam dela, e, assim, constitui-se na correlação e na experiencia da intimidade.

26 YOUTUBE. Iza debate a mulher com Lázaro Ramos, Espelho. Disponível em: https://www. youtube.com/watch?v=mF8n_iGJYL0. Acesso em 15 jul 2020. 
Mas, não é sem dor que Iza colabora para desmascarar impostores, criticar a disciplina da pureza, a qual costumeiramente se traveste de luta anticorrupção, o cuidado com a criança, manietada pela identidade conservadora. Ao expor sua dor - "ser mulher é difícil"; "pensar quinze vezes na roupa que vai usar antes de sair de casa"; "A gente tem que tá pensando em como falar alguma coisa"; "passa por provação o tempo inteiro"; -tanto quanto, elabora o luto que constrói seus processos de identificação, "eu estou em construção".

Sabe-se que a dor do luto renegado produz identidade. Rasura a identidade heterossexual uma vez que "se baseia na recusa de reconhecer um apego e, por conseguinte, na recusa de prantear" (BUTLER, 2017, p. 147). Essa dor não lastimada, esse luto mal resolvido produz cicatrizes na alma e deve doer por demais, além de como se viu, produzir castração, imposição, violência, crueldade. Mas, por outro lado, sem performatizar o luto há como se sair de um estágio infantil e pedante que evoca piadinhas como se estivéssemos na 8aㅡ série do Ensino Fundamental, ocupados com "mamadeira de piroca" e outras analogias toscas de fixação anal?

Ora, para rebater críticas do jornalista estadunidense Glenn Greenwald, qual seja, "Bolsonaro é um cretino fascista por razões que não têm nada a ver com os elogios de Maia. Isso reflete mal em Maia, não em Bolsonaro", o àquela época deputado e candidato presidencial escreveu: "Você queima a rosca? Eu não ligo! Seja feliz! Abraços para você!".

Figura 3 - Eu não me importo

Jair M. Bolsonaro
"Do you burn the donut?" I don't care! Be happy! Hugs for
you!
Em resposta a @Gerson775 e @jairbolsonaro
Braise. This reflects poorly on Maia, not Bolsonaro.
11:59 AM · 4 de set de 2017
013,7 mil $\quad$ 6,2 mil pessoas estão tweetando sobre isso

Fonte: O GLOBO. Brasil. Chamado de "fascista”, Bolsonaro ataca orientação de sexual de jornalista. 4 set. 2017. Disponível em: https://oglobo.globo.com/brasil/chamado-defascista-bolsonaro-ataca-orientacao-sexual-de-jornalista-21783351 Acesso em: 10 jul 2020.

A dor sexual recalcada e, como já apontado por Michel Foucault, sempre falaremos de sexualidade ao tratar de identidade, a angústia reverberada na menoridade, denuncia uma forma de convicção identitária múltipla e contraditória, porque se baseia no domínio e no prazer, na ansiedade e na defesa, no ataque e no cínico "abraços para você". A dor recalcada se fundamenta no estereótipo e na trapaça política. Como não se 
tem ou não se pode dizer algo sério sobre o assunto, diz-se que o oponente "queima a rosca". Em face da piada homofóbica corrente, simplifica-se qualquer possibilidade de se representar o outro em sua possível inteireza, qual seja, em devir. 0 sistema de sentidos é interrompido e se categoriza o outro por meio da pergunta retórica: "Você queima rosca?" A resposta é elíptica: sim. "Eu não ligo!".

Ao se suspender o jogo das diferenças, se cria um problema para o outro, o de uma representação em acepções de relações de ódio de gênero. 0 estereótipo impede a circulação do discurso que realmente importa. Estava tratando do que mesmo o jornalista Glenn Greenwald em sua crítica?

O estereótipo trava o discurso e passamos a ver Greenwald não como um redator a fazer uma crítica e uma denúncia grave, mas como um anormal, um degenerado, um "queima rosca". Glenn se transforma no "outro" do poder fetichista, circulando dentro do discurso da modernidade/colonialidade numa forma precária da diferença.

O discurso bolsonarista construiu uma identidade fixa por meio de um ato de negação agressivo e fixação de papéis, retrocedendo ao narcisismo infantil de seu Imaginário e à sua identificação de um ego ideal branco, heterossexual, judaico-cristão e supostamente inteiro e não marcado pelo outro.

Se acolho a ideia de que identidades são representações, construções da realidade, uma idealização arbitrária, diferencial e sistêmica de signos sociais e culturais, como não perceber que o pensamento conservador é ultrapassado? Não apenas isso, guarda em si algo de brega, cafona e mofado, gesta fascismos, segregação, reativa os horrores do fundamentalismo, produz inimigos e o pouco respeito ao ensino público e a estudos sérios e de qualidade. Sua identidade ig- norante abrange o não saber e o não querer saber, o que lhe faculta deturpar a realidade para encobrir mecanismos de exclusão. De sua ignorância nasce o revanchismo, signo do recalque contra as universidades, as escolas, as professoras e os professores. A Associação Nacional dos Dirigentes das Instituições Federais de Ensino Superior (Andifes) tem destacado que as universidades são alvo constante de "retórica agressiva", a qual detrata e ofende essas instituições perante a opinião pública, estigmatizando-as inclusive, como organizações criminosas ${ }^{27}$.

Há relação entre a identidade conservadora e certa crise com a educação formal, o que beira a irresponsabilidade cognitiva e a suspeita de crimes de várias ordens. No Brasil, para além de encontros com Jesus na goiabeira, germinam-se sementes como as da "terra plana", do "movimento antivacina", das teorias de conspiração gay e comunista e da negação do aquecimento global ${ }^{28}$.

Trata-se de fulcral desprezo pelo saber científico que envida cloroquina a pacientes com Covid-19, mesmo após a Organização Mundial da Saúde (OMS) determinar a suspensão de testes com essa droga, haja vista estudos que demonstram aumento no risco de morte de pacientes ${ }^{29}$. Tudo isso num ce-

27 UOL. Educação. Sem provas, Weintraub diz que federais têm plantações extensivas de maconha. Disponível em: https://educacao. uol.com.br/noticias/2019/11/22/weintraubha-plantacoes-extensivas-de-maconha-emuniversidades-federais.htm?cmpid=copiaecola. Acesso em 10 jul 2020.

28 G1. PROFISSÃO REPÓRTER. Terra plana, vacinas e aquecimento global: um terço dos brasileiros ainda desconfia da ciência. 11 dez. 2019. Disponível em:https://g1.globo.com/profissao-reporter/ noticia/2019/12/11/terra-plana-vacinas-eaquecimento-global-um-terco-dos-brasileirosainda-desconfia-da-ciencia.ghtml. Acesso em 10 jul 2020.

29 G1. BEM ESTAR. Ministério da Saúde mantém indicação de cloroquina após OMS suspender uso. 25 mai. 2020. Disponível em: 
nário em que a ministra Damares precisou da intercessão divina para defender seu "mestrado": "diferentemente do mestre secular que precisa ir a uma universidade para fazer mestrado, nas igrejas cristãs é chamado mestre todo aquele que é dedicado ao ensino bíblico"30. 0 que dizer então de ministro da Educação que não obteve título de doutor e está sendo acusado de plágio em trabalho de conclusão de Mestrado ${ }^{31}$ ?

As dores recalcadas durante o processo de constituição da identidade conservadora heterossexual, cisnormativa, branca e patriarcal, retornam sob vestes diversas, sejam sob a capa de piadas homofóbicas, chistes racistas e fixação no sexo anal gay, sejam sob a expressão vil da morte.

Em 2019 foram 1.314 mulheres mortas pelo fato de serem mulheres, trata-se de uma a cada 7 horas, em média ${ }^{32}$. Nesse

https://g1.globo.com/bemestar/coronavirus/ noticia/2020/05/25/saude-mantem-indicacaopara-uso-de-cloroquina-e-hidroxicloroquinano-tratamento-da-covid-19.ghtml. Acesso em 10 jul 2020.

30 FOLHA DE PERNAMBUCO. Blog da Folha. 30 jun. 2020. Não foi só Decotelli. Outros políticos também tiveram títulos acadêmicos no currículo contestados. Disponível em: https:// www.folhape.com.br/colunistas/blogdafolha/ nao-foi-so-decotelli-outros-politicos-tambemtiveram-titulos-academicos-no-curriculocontestados/18790/. Acesso em 10 jul 2020.

31 GAZETA DO POVO. EDUCAÇÃO. Ministro da Educação não fez pós-doutorado na Alemanha, diz universidade. 29 jun 2020. Disponível em: https://www.gazetadopovo.com.br/educacao/ ministro-da-educacao-nao-fez-pos-doutoradona-alemanha-diz-universidade/ Acesso em 12 jul 2020.

32 G1. MONITOR DA VIOLÊNCIA. Mesmo com queda recorde de mortes de mulheres, Brasil tem alta no número de feminicídios em 2019. 05 mar. 2020. Disponível em: https://g1.globo.com/ monitor-da-violencia/noticia/2020/03/05/ mesmo-com-queda-recorde-de-mortes-demulheres-brasil-tem-alta-no-numero-defeminicidios-em-2019.ghtml Acesso em 12 jul 2020. mesmo ano, ocorreram 329 mortes de pessoas LGBT+, uma a cada 26 horas, em média. Feminicídio e homofobia são a outra face da moeda: "rosa para meninas e azul para meninos", desde que esses não queimem a rosca.

O lugar social do sujeito e as relações de poder que o definem determinam em grande parte a forma como se compreende sua identidade. Por outro lado, a identidade é produto das representações sociais que determinam os lugares que as pessoas devem ocupar na sociedade. A identidade conservadora se opõe francamente a novos arranjos. Daí suas narrativas buscarem centrar o sujeito.

Por que seu apego desesperado à tradição? Porque assim seguem mantendo seus privilégios e determinando certos lugares para os outros como objetos enclausurados em identidades rebaixadas, desprovidas de segurança ontológica e justiça, prontos a toda ordem de exclusão. Urge então, na contramão da tradição, evocar a possibilidade do diferimento, do adiamento do sentido, que sempre "já" é outro, sendo ele inapreensível. Fundamental se torna questionar todo e qualquer discurso que teime em reivindicar para si "a" autoridade na busca idealista, fundamentalista, fascista de significados, muitas vezes travestidos de nacionalistas e não ideológicos.

A identidade reacionária remonta a genocídio, ao massacre diário pela luta em torno das terras, à casa grande e à senzala, aos sobrados e mocambos. Não é possível esquecer a agrura cotidiana do sexismo, da violência contra sujeitos cujas sexualidades são dissidentes. Não se deve olvidar discursos do tipo "você sabe com quem está falando": "Cidadão não, engenheiro civil formado, melhor do que você"33.

33 CATRACA LIVRE. CIDADANIA. Mulher flagra- 
Logo, que identidade se nos importa? Importam identidades flutuantes cujo movimento produza o aumento da sensibilidade contra a opressão social, na tentativa de reduzir e eliminar essas desigualdades. Interessa fomentar identidades perturbadoras, agonísticas e em devir na contramão da ignorância branco-patriarcal-judaico-cristã. Talvez assim possamos ter uma outra era no Brasil.

\section{Considerações finais: gestos equívocos}

Se concordarmos que não há centro, se não há uma verdade verdadeira a ser apanhada, fica demandada alta importância à "interpretação", ao pensamento crítico e às identidades cambiantes como geradoras de significação, não cabendo convocar à cena uma pretensa neutralidade e transparência da razão. Sendo a "interpretação" de alcance ilimitado, ela mesma um "jogo" que se esvai, que desliza, não há, pois, como apreendê-la, como dela se apropriar num fechamento. Este pensamento questionador coloca em suspeita toda identidade reacionária, exatamente porque enquanto linguagem, todos os discursos, textos, ficções são obra de retórica e de "jogos" presentes à vida que se protege por repetição, traços, diferenças e adiamento.

Isso não quer dizer que a interpretação seja uma panaceia para os problemas do mundo. Compreendo que "a interpretação deve falar de algo que deve ser encontrado em algum lugar, e de certa forma respeitado" (ECO, 2005, p. 50), tanto quanto estou convencido de que vivemos um tempo em

da pelo "Fantástico" humilhando fiscal no Rio é demitida. 06 jul. 2020. Disponível em: https://catracalivre.com.br/cidadania/mulherflagrada-pelo-fantastico-humilhando-fiscal-embar-no-rio-e-demitida/ Acesso em 12 jul. 2020. que os referentes se fazem ausentes, os significados foram diferidos, os sujeitos divididos, o jogo de significantes é atravessado por um campo de forças cósmico, a hiper-realidade e a simulação nos tomam de assalto, as tradições são imaginadas. Como então interpretar o que quer que seja senão atentando para o contexto, para os jogos de poder, para as ideologias e os interesses (morais, sexuais, pulsionais, econômicos)? Como interpretar sem pensar no "desejo" da presença, no apego ao "um", na ânsia pela verdade? Como interpretar por meio dessa língua, dessa palavra que suspostamente é minha?

A "minha" palavra é parte/resultado de um jogo de poder que pretende controlar o "meu" discurso, selecionando o que pode e o que não pode ser dito e em que condições. Entrelaçada à língua na qual escrevo (a qual acredito saber falar, e da qual tenho sempre medo, porque, nunca dizendo o suficiente, sempre digo além da conta), "minha" palavra enquadra e coordena as opções metodológicas e as categorias de análise aqui destacadas. A "minha" palavra, "já" é tradução, porque faz parte de um movimento metafórico de transporte de sentido, e metonímico, haja vista sua condição de transportar sempre a parte e não o todo. 0 que poderia chamar, pois, de ato tradutório (não numa concepção mecânica e idealizada da tradução) questiona conceitos como autoria, verdade, assinatura, porque lida com a negociação, com o trânsito, com a transferência de, com paixões, sentimentos, agressões e transgressões possíveis e possibilitadas.

Jacques Derrida, filósofo franco-argelino, abordou em seus estudos questões caras como o "logocentrismo", qual seja, o privilégio do discurso falado sobre o escrito, o "fonocentrismo", a saber, o centramento na phoné, ou seja, ao ouvir-se falar, a própria 
voz seria tomada como índice da unidade discursiva, sendo em si um discurso com uma única voz, e o "falocentrismo", baseado no phallus, o poder da presença, a virilidade como centro de uma "presença presente", de uma "metafísica da presença", de uma origem simples e não contraditória, cujo centro seria fixo, permanentemente remissível em sua articulação. Ao problematizar esses termos denunciou equívocos construídos pela metafísica ocidental e produziu uma ética da aporia.

Tal ética possível impossível, infinita em sua hospitalidade não se deixa acometer por identidades bem marcadas e resolvidas e "permanece sempre a meio caminho" (NASCIMENTO, 2005, p. 13). Investe na intensificação e acolhimento da tensão, na chance de abertura para o inusitado, para o acontecimento paradoxal, determina-se enquanto não cedendo a nenhuma determinação, localiza-se enquanto não se atendo a nenhum lugar, detendo-se enquanto deslocável (RIBEIRO, 2008, p. 235).

Em entrevista cedida a Henri Ronse, Julia Kristeva, Jean-Louis Houdebine e Guy Scarpetta - os quais Derrida chama de "interlocutores" -, o filósofo da desconstrução denominou seu trabalho de "posições", palavra cuja polissemia se marca pela letra "s", marca "disseminante" (DERRIDA, 2001, p.32). A disseminação não se ocupa de "todos" os sentidos (de uma palavra), menos ainda do ser do sentido, é o devir sem fim, a substituição da substituição, um “jogo" que representa mais do que apresenta, que não tem em si nenhuma verdade a ser desvelada porque não se trata de buscar "a" verdade em face de uma identidade ressentida e nostálgica.

Nesse "jogo" não há "sujeito", não há "referência privilegiada", não há "origem absoluta", não há "centro". Trata-se da possibilidade de o signo produzir um número infi- nito de efeitos semânticos, sem, contudo, se deixar reduzir a um presente transcendental de origem simples.

0 descentramento derridiano coloca o dedo na ferida do "significado último" da identidade conversadora. Ora, se não há "centro", se não se encontra o "fundo", somos convidados a lidar com "a escrita de uma escrita" (NASCIMENTO, 2005, p. 98), qual seja, a possibilidade de que uma identidade sempre se remeterá, infinitamente, a outra que se deslocando, difere e posterga ad nauseum o sentido último.

Minha tese - e quando digo "minha", deve-se ler "supostamente minha" porque nasce endividada a uma herança, a um conjunto de leituras e escrituras -, é assombrada por legiões de fantasmas, os quais nem concebo e nem cabe aqui tentar identificar. São pessoas, livros, pensamentos, filmes, músicas, tradições, nomes, gritos de guerra, roupagens, sonhos e contra-sonhos, que formam a "minha" palavra, essa que "já" não é "uma" palavra, essa que "já" não se pega mais, que é sempre mais de uma, que escorrega num cipoal de palavras dentro de uma palavra, à moda de uma injunção desajuntada. Estendendo o fio, a herança de qualquer tese, de qualquer pensamento e palavra, rasura todo "meu" eu possível e aponta para uma necessária - tremenda e agressiva - desapropriação. Logo, toca-me apontar que toda tese assim como toda identidade, é sempre fendida, dividida, contraditória, sempre se deslocando porque, prenhe de conceitos, categorias, taxonomias, não fazem nunca um consigo mesmo. Sua estrutura tal qual um arquivo (DERRIDA, 2001) é espectral.

A espectralidade atemoriza o capitalismo e o liberalismo global que evocam sempre o "meu", a "minha", a "minha propriedade", a "minha mulher", a metafísica da propriedade, "da propriedade mais fascinante e feti- 
chista que pode haver na era do capitalismo imaterial: a própria identidade" (DUNKER, 2017, p. 298). Essa expropriação se coaduna com a desapropriação de si, do "eu”, do sujeito e concebe que o eu se constitua não a partir de um fundamento, mas de uma im -propriedade, de uma in-exatidão, qual seja, a de se construir a partir da relação com os outros, despossuindo-se, desmanchando-se.

Em outros termos, toda identidade, toda tese, todo "eu", todo "todo" só se constitui atravessado por forças, circunstâncias, contingências, rearranjos, choques, continuuns, reservando sempre um delicado problema de tradução. Sim, de tradução porque a todo sentido sempre se perguntará, que será que se quis dizer? $\mathrm{Ou}$, pelo menos, no momento, o que é que se é dado a escutar? 0 que se permite compreender à porta de todo futuro - que sempre é outro -, em que o tempo não é homogêneo?

Minha tese para pensar a identidade, dentro da chave dos "Estudos da Diferença", detidamente, atravessada pela desconstrução derridiana, é a de que a identidade só é interessante se for extrema, se estremecer preservando o tremor do deserto do deserto, cuja deslocalização, abre o outro para um lugar sem lugar do pensamento, ali mesmo onde as incertezas se produzem e nos convidam a decidir, se se espelhar na angústia úmida do nada e para o nada e daí, transbordar colaborando para a anulação de toda diferença ontológica, rígida, hiperbólica e por vezes, cínica, fazendo ruir toda possibilidade de privilégios. Digo, a identidade só será interessante se for úmida, erótica, mestiça, em devir, em différance.

\section{Referências}

BUTLER, Judith. A vida psíquica do poder: teorias da sujeição. Belo Horizonte: Autêntica Editora, 2017.
CASTRO-GÓMEZ, S.; GROSFOGUEL, R. (Ed.). El giro de colonial: reflexiones para una diversidad epistémica más allá del capitalismo global. Bogotá: Siglo del Hombres; Universidad Central, Instituto de Estudios Sociales Contemporáneos y Pontificia Universidad Javeriana, Instituto Pensar, 2007

DERRIDA, Jacques. A escritura e a diferença. São Paulo: Perspectiva, 2009.

DERRRIDA, Jacques. Margens da Filosofia. Trad. Joaquim Torres Costa e Antonio M. Magalhães. Campinas: Papirus, 1991.

DERRIDA, Jacques. Posições. Tradução: Tomaz Tadeu da Silva, Belo Horizonte: Autêntica, 2001.

DERRIDA, Jacques. Esporas: os estilos de Nietzsche. Rio de Janeiro: Nau, 2013.

DUNKER, Christian Ingo Lenz. Reinvenção da intimidade: políticas do sofrimento cotidiano. São Paulo: Ubu, 2017.

ECO, Humberto. Interpretação e superinterpretação. Tradução MF: revisão da tradução e texto final Monica Stahel. São Paulo: Martins Fontes, 2005.

Haddock-Lobo, Rafael. Para um pensamento úmido: a filosofia a partir de Jacques Derrida. Tese, Doutorado em Filosofia, Pontifícia Universidade Católica do Rio de Janeiro, Rio de Janeiro, 2007.

HAIDER, Asad. Armadilha da identidade: raça e classe nos dias de hoje. São Paulo: Veneta, 2019.

Krenak, Ailton. Ideias para adiar o fim do mundo. São Paulo: Cia das Letras, 2019.

Miskolci, R., Campana, M. "Ideologia de gênero": notas para a genealogia de um pânico moral contemporâneo. Sociedade e Estado, UNB, 32(3), 2018.

NASCIMENTO, Evando (org.). Jacques Derrida: pensar a desconstrução. Tradução Evando Nascimento. São Paulo: Estação da Liberdade, 2005.

Osaniiyi, A. Em torno de uma epistemologia preta. Universidade Federal do Oeste do Pará, UFOPA: Revista Exitus, 9(4), 17 - 36.

RIBEIRO, Alexandre Simões. 0 litoral d'Aporia: uma introdução a psicanalise lacaniana. Rio de 
Janeiro: Garamond, 2008.

SAID, Edward. Cultura e imperialismo. São Paulo: Companhia das Letras, 2011.

SLOTERDIJK, Peter. Derrida, um egípcio: o problema da pirâmide judia. Tradução: Evandro Nascimento. São Paulo- Estação da Liberdade, 2009.
WALSH, C. Son posibles unas ciencias sociales/culturales otras? Reflexiones en torno a las epistemologías decoloniales. Nómadas, n. 26, p. 102-113, abr. 2007.
Recebido em: $27 / 07 / 2020$

Aprovado em: 26/09/2020

(c) (i) Esta obra está licenciada com uma Licença Creative Commons Atribuição 4.0 Internacional. 